\title{
Looking at human development through the lens of Christian mission
}

Author:
Akinyemi O. Alawode ${ }^{1}$
Affiliation:
1'Department of Theology,
Faculty of Human and Social
Sciences, North-West
University, South Africa
Corresponding author:
Akinyemi Alawode,
akinalawode@gmail.com
Dates:
Received: 18 Nov. 2015
Accepted: 03 May 2016
Published: 26 Oct. 2016
How to cite this article:
Alawode, A.O., 2016,
'Looking at human
development through the
lens of Christian mission', In
die Skriflig 50(1), a2063.
http://dx.doi.org/10.4102/
ids.v50i1.2063
Robile device
to read online.
Copyright:
Q 2016. The Authors.
Licensee: AOSIS. This work
is licensed under the
Creative Commons
Attribution License.

\begin{abstract}
Approximately one billion people live in extreme poverty, with another two billion people surviving on less than $\$ 1$ per day. Many of them, living in abject poverty, struggle with ill health, limited access to clean water, hygienic sanitation, poor quality housing, hunger, illiteracy and premature death. However, improving the lives of the poor is a complex undertaking with often little agreement as to how can this be best achieved. The intrinsic goal of development is to advance human dignity, freedom, social equity and selfdetermination. Moreover, there is no univocal definition of development. In this article my own understanding will be discussed more extensively. My conviction that development, in general in the context of Christian mission, finds its roots in Christian empathy with people in dire need will be stated.
\end{abstract}

\section{Introduction}

One can argue that development, as another dimension of Christian mission and missiology (as we understand it today), has its roots firmly in the history of the outreach of the Christian community since its very beginning. ${ }^{1}$ This pattern was repeated in Sub-Sahara Africa, Asia and elsewhere during the modern Western mission movement in the 18th and 19th centuries (Bosch in Saayman 1992:45). Thus, in a very general way, one can state that some form of development was an integral dimension of Christian mission from the earliest years.

I choose to deal with the situation, especially since around the 1960s (in other words, the years after the Second World War). The years following the Second World War (1939-1945) brought great changes to self-understanding in the Western colonialist powers as well as their relationships to their (previous) colonies. As Bosch (1979:177) describes the context of the first post-war meeting of the International Mission Council (IMC) in 1947 in Whitby, the delegates realised that one world (the old, pre-war Western Europe) was dying, while the rest of the world was going through birth-pains in an attempt to bring a new world into being. Mission, at least as it was represented in the IMC, was therefore characterised by a new realisation of its bond with the world. This brought new emphasis on the old link between mission and development. ${ }^{2}$ This led to the fact that 'development' was indeed regarded as the key word at the momentous Uppsala Assembly of the World Council of Churches (WCC) in 1968 (Bosch 1979:190). ${ }^{3}$ In terms of Bosch's analysis (1979:191), this was therefore not simply a contextually-inspired development - it was the result of the growth of a new, specific spirituality: a spirituality I wish to describe as characterised by a compassionate life in the social justice tradition. This missionary responsibility to participate in the struggle for justice and human dignity, which could mainly be brought about through participation in development, was especially strongly emphasised at the WCC Assembly in Nairobi, Kenya in 1975 - an assembly characterised by Saayman (1980:119-127) as the beginning of a new direction (especially in terms of overcoming the Ecumenical-Evangelical confrontation).

At this stage of the discussion the meaning and content of the concept development was rather onesidedly determined by First World theology, sociology and economics. However, by the late 1960s and early 1970s this established concept was being questioned under the growing influence of 1.Bosch (see Saayman 1992:44) refers to the well-known reality that the first hospitals in Europe grew out of this ministry. Churches in
Europe also became involved in some of the earliest attempt at providing education to equip people to deal with everyday life.
2.Newbigin mentions in an address after the Second World War how, in his position in the IMC, he had to become used to the priority of
mission-as-(development as)-Inter-Church Aid, over mission-as-evangelisation-and-churchplanting. It is important to note that
development understood in terms of the Western political economy (especially as incarnated in the Bretton-Woods Institutions) was
the reigning interpretation in those days. under the influence of Hoekendijk also played a very important role (Bosch 1979:178-180, 190).

Note: This article is a reworked version of the author's PhD thesis: 'Constructing mission praxis for sustainable socio-economic development amongst the rural poor of Oluyole local government (Oyo State), Nigeria of 2013'. 
input from Third World Liberation Theologies (Latin American, African and Asian - Kritzinger in Saayman 1992:280). This played a role of growing importance in shaping the direction and content of the debate over what the meaning and content of development should be. Liberation theologians from the three continents mostly colonised (South America, Africa and Asia) were clearly expressing their disillusionment with the fruits of development, propagating the term liberation to replace it. To simplify a very complex debate, one can say that they were stating: surely, our people need development - but what kind of development? Who decides what is most urgently needed? And, very important: Who sets the agenda when we are discussing development schemes? (cf. Kritzinger in Saayman 1992:280-282). There was good reason to ask these questions, because by the 1980s it was clear that the great post-war expectations about the contribution of development, also in mission circles, were not going to be realised. Perhaps the two most obvious reasons for the general failure were the introduction of unsuitable schemes, and corruption on a tremendous scale in the allocation and utilisation of the funds. ${ }^{4}$ There was another motivation, though, that was true especially in relation to Africa. Africa had in those days seldom been provided the opportunity 'to interpret and present itself on its own terms to the rest of the industrialised world' (Saayman 2003:58). It is generally acknowledged today that during the Cold War era (more or less post-World War II until 1989) the 'major powers' of the industrialised world viewed their involvement in Africa (also in terms of development funding) mainly in terms of their perceived strategic interests. By the early 1990s the failure of many of the well-meant development schemes as well as the growing popularity of Liberation Theologies, in the context of post-Cold War globalisation, led to a shift in the debate signifying the waning importance of the established meaning, scope and role of development in the missiological debate. ${ }^{5}$ It is our contention that in any consideration of the future of missiology, development must return to its rightful place of priority especially in Sub-Sahara Africa. There is, however, an important proviso here: it must be development as described by Africans themselves - it cannot simply be a re-imposition of an imported model.

\section{Sustainability of Socio-Economic development}

It is obvious that I need to be quite clear on my definitions of development, especially sustainable socio-economic development. There has been a remarkable escalation in the literature of the use of the phrase socio-economic development in that it has become public property. The meaning of the phrase is always highly contested in the development debate as well as in missionary enterprise. The phrase has many

4.As far as the unsuitability is concerned, we can refer to two well-known (African) examples: a consignment of snow ploughs sent to Ghana and the introduction of examples: a consign inent of snow ploughs sent to Ghana and the introduction of mainly homegrown, with corrupt (African) leaders and political elites grabbing hold of much of the funds for their own advantage.

5.The failure and the resultant waning of interest in issues of development are discussed more widely in Saayman (2003:69-71). meanings. Socio-economic development, according to August (2006:4), is a capacity defined by what people can do with whatever they have to improve their own quality of life and that of others. Development embodies a desire, motivation and knowledge for sustainable livelihood. Burkey (1993:34) observes that development concerns people - it affects their way of life and is influenced by their conceptions of the good life as determined by their cultures or ethnicity. Many governments define development as building new towns, hospitals, clinics, schools, roads, et cetera. In churches, development is described as anything pertaining to a person's physical and spiritual growth. To some people, development necessarily involves structural transformation that implies personal, political, social and economic changes. Socio-economic development is not just a question of infrastructural projects such as schools, clinics, roads and dams as some people think. Development means a process of enabling people to accomplish things that they could not do before - that is to learn and apply information, attitudes, values and skills previously unavailable to them. Development is one of the most talked-about objectives of every person and every government or institution. Genuine socio-economic development, however, is the creation of adequate capacity (human resources) in every organisation. Development depends a lot on human knowledge (mental wealth) and skills, and where this knowledge and these skills are inadequate to the task in hand, socio-economic development will be thwarted. The development of human resources must include cognitive and affective development, physical development, and the development of suitable attitudes and worldviews. It is also a systematic procedure of training and growth in which communities gain and apply knowledge, skills and insights to their situation. This leaves me with a very broad and general understanding of development and therefore a brief historical overview of recent trends in relationships between development and mission are hereby considered.

\section{A brief historical overview of recent trends in relationships between development and mission}

It is obvious that an overview of the totality of the relationships between development and mission throughout the entire history of the Christian church cannot be provided in this article. ${ }^{6}$ Three phases through which the church had passed over the years in relation to community development will be looked into under this topic. There is a critical approach to the modernist paradigm and a consequent move towards transformational development as a new approach.

\section{Development as modernisation}

The 1960s were characterised by the dominant understanding of development as modernisation. This meant that the technological development of the West was considered to be the answer to development in the third world. In her own 6.For a more extensive overview, see Alawode and Saayman (2013). 
view, Van Schalkwyk (1996:48) states that 'It meant that the technical and economic development within the capitalist framework was considered to be the universal remedy or magic potion for all socio-economic problems'.

Development was also understood as an inherent to the process of colonisation. Even the church fell into the trap of facilitating this kind of development. At this stage there was a clear identification between development, mission and political power in colonies and previous colonies all over the world.

For the church this stage meant missionaries working to bring about Western civilisation that they thought would solve the problems of poor Third World countries and was a form of colonisation by the First World. This harks back to sentiments expressed by earlier missionaries. These sentiments were clearly expressed by John Phillip, who was the Superintendent of London Missionary Society in the Cape in 1819. Phillip stated that 'while our missionaries are everywhere scattering the seeds of civilization, social order, happiness, they are by the most unexceptional means extending British interest, British influence and the British Empire' (see De Beer 1997:26).

\section{Moreover, Phillip also wrote in De Beer (1997) that:}

Missionary stations are the most efficient agents, which can be employed to Promote the internal strength of our colonies, and the cheapest and best military Posts that wise governments can employ to defend it against the predatory Intrusions of savage tribes. (p. 27)

To civilise and Christianise were perceived as a calling, because the African way of life was seen as primitive, barbaric and pagan. It therefore had to give way through development to the so-called Christian life.

\section{Critical acceptance}

It did not take long for the deficiencies of this approach to the development of the poorer countries to be realises. Two important factors were appreciated: firstly, that development is more than economic growth; secondly, that development, over and above the creation of projects and programmes, has to take seriously the development of the people.

If the church understands development as economic growth, this will limit her (the church) perspective, because it would not take into account 'the total or complete process of human and social development' (De Beer 1997:27).

Developmental programme should be done in such a way that the poor people would be able to see and appreciate the ethical implications of the involvement of development in all aspects - economic, social, political and cultural - of their lives. Our approach to development should be people-centric or humanistic (Van Schalkwyk 1996:48), due to the fact that this new approach promotes the perception of development as liberation. Also, it is viewed as the radical breakdown of an oppressive and negative status quo so as to free the poor and the oppressed. This goes hand in hand with the understanding of development as liberation, which means the struggle against the oppressor and breakdown of oppressive systems that did not consider the poor. Liberation theology helps us to better understand the connection between faith and the needs of the world - particularly the poor people.

Liberation theology invites people to respond to the gospel in profoundly concrete ways, and to establish relationships of solidarity and community. When it is sincerely put into practice, our faith would make sense and Christian interaction with the world will be better-off and more meaningful, because the delights and expectations, the doubts and worries of the people of this age, especially the poor, are those of the church. Liberation theology therefore captured the hopes and the yearnings of the poor people.

However, I think at the very least that liberation theology is a reflection on the fact that human liberation has to be part of the Christian understanding of salvation. Salvation is not exclusively otherworldly - it has something to do with the here and now, because poor people were beginning to long for a change that would alter the traditional relationship in which the church was more associated with those in power (Faith in real life 2013). Liberation theology's understanding of Jesus is part of a wider 21st century appreciation of the historical Jesus and his ministry. It was not a purely strange kind of preaching. Jesus reached out to people, especially those who were rejected in the society. It provides a model for where the church should be, and that the church is being invited to look at the crucified (poor or the vulnerable) people of our own world today and ask them these questions: What have I done to crucify you? and What do I need to do to bring you down from the cross? Through this, liberation theology would be able to produce the transformative lens of faith through which the life of the poor people would be able to change for better.

\section{Towards transformational development}

The humanist approach to development emphasised development as liberation, which meant the removal of oppressive structures. A new paradigm emerged that moved away from developmentalism. This paradigm emphasised the need for development to be viewed as the transformation of society. This transformation was coming not from above (something planned by some people and imposed on the poor), but also from below (something planned by the people themselves). With this method the poor people will be fully involved in shaping their own future. Through this they now become important role players or participants in developmental processes of their own lives.

Anne Hope (see Van Schalkwyk 1996) goes on to mention another approach; according to her there is a need to go further by building a new society - a process she calls social 
transformation. This term refers to the building up of an alternative society with new values and a new order. Now development can be understood to mean social transformation that transcends liberation in the sense of a simple breaking down of old systems. In fact, understanding this kind of development can be traced by considering the early stages of development. It started as modernisation, and then moved towards a comprehensive approach that was humanistic. It then became liberation, and lastly it is understood as the building of a new society. Social transformation development refers to the process of change in values, norms, institutionalised relationships and stratification hierarchies over time. It affects patterns of interaction and institutional arrangements within a society. The course of social transformation in any given society depends upon the specific historical events (in Van Schalkwyk 1996:48).

However, many of our churches today are engaged in suicidal transformation. This is an act that is damaging to the church's own interests instead of involving in societal transformation that could bring life to the people and the church herself. As a church, the following serious questions have been asked: Are we actively engaged in the difficult task of transformation that embraces the social, the economic and the spiritual? Are we making a lasting influence on the society? What is the score of the church in this whole issue of spiritual and social transformation? These questions are asked, because it is believed that the church should have overpowering influence on the society (Transform world 2009).

Transformational development is reaching the community with the whole gospel for the whole person through whole churches. Social action and evangelism go hand in hand. The community recognises that the churches' role is not only to teach and preach the Word of God, but also to be involved in transformational development. We must preach the gospel through words and deeds. We must not dichotomise evangelism and social activism - they always go together. We must practice both personal and social holiness.

Moreover, drawing on official World Vision (WVI) documentation, transformational development is, ideally, a holistic and sustainable development process that is community based, and a process in which individuals, families and communities identify and work to overcome the root causes of their poverty or 'the obstacles that prevent them from living life in all its fullness'. Transformational development adopts an 'integrated physical-spiritual' view of the people, the world and the development process (WVI 2003:6). The scope of transformation development is intended to be inclusive of social, spiritual, economic, political and environmental dimensions of life (WVI 2003:16). The goals of transformational development and the process whereby it is pursued, are framed within the biblical narrative of the kingdom of God, but incorporate developmental insights and practice alongside the mobilisation of religious resources (WVI 2003:36).

The 'domains of change', which transformational development seeks to impact, include wellbeing (families and communities), empowerment (of individuals, to be agents of transformation, and of communities, to function sustainably and interdependently), transformed relationships (with self, God and others, reflecting both love and justice) as well as transformed systems and structures (WVI 2003:24). Transformation is the change from a condition of human existence contrary to God's purposes to one in which people are able to enjoy fullness of life in harmony with God. Bryant (1999:3) uses the term transformational development to reflect his concern for seeking positive change in the whole of human life materially, socially and spiritually. He (Bryant 1999) stated further that:

Changed people and just and peaceful relationships are the twin goals of transformation ... Changed people are those who have discovered their true identity as children of God and who have recovered their true vocation as faithful and productive stewards of gifts from God for the well-being of all. (p. 14)

Also the Opportunity International Network (OIN) defines transformational development as 'a deeply rooted change in people's economic, social, political, spiritual and behavioral conditions resulting in their enjoyment of wholeness of life under God's ordinances' (Opportunity International 2000). God's design, and people conforming to it, is two common concepts that are advanced by these definitions. More specifically, these definitions not only embody the broader impact areas of secular development, but also hold them accountable to a greater purpose for human existence. In other words, transformational development concerns change in all aspects of life - economic, social, political, spiritual and emotional - with a clear understanding of the ultimate purpose and goal of such development. Transformational development deals with the whole person. Every person is inherently an economic, a political, social and spiritual being at the same time. The transformation of the whole person means the simultaneous death of the old and the living to the new. Herein lays the interaction between spiritual transformation and transformational development, because God's purpose and design for human existence implies spiritual transformation. Therefore, development theories and programmes that do not address an individual's personal relationship with Christ are inadequate. While this central point of transformational development is critical to my working definition, one must also remember with equal passion the multiple relationships that also must be reconciled to God's intended purpose and design. There are four major areas of reconciliation that Christians recognise to take place for holistic transformational development to occur. These are the reconciliation of people to God, with themselves, their neighbours and the rest of creation (Medicalteams 2013).

\section{Theological framework for human development in relation to Christian mission}

It is my conviction that the theological framework for development can be found in Christian mission. Therefore mission as used in this article will now be described. 
Over the years, 'mission' has become a controversial topic (Kritzinger \& Meiring 1989:33). People no longer mean the same thing when they speak of 'mission'. In fact, they all have their own perception of what mission is. David Bosch (1991) lists a number of meanings attached to this word:

1. The sending of missionaries to a designated territory.

2. The activities undertaken by such missionaries.

3. The geographical area within the overall territory where the missionaries .

4. The agency that dispatches missionaries towards mission fields, the non-Christian world, or local congregation without a minister. (p. 1)

The definition of mission has change over the years with the development of the debate on what mission is and what its purpose is. For instance, earlier definitions of mission as evangelism, which emphasised the preaching, witnessing and proclamation of the gospel (Kritzinger \& Meiring 1989:33), are currently understood to be very narrow. These definitions see people simply as souls in need of conversion: once that is done, mission is accomplished. They do not include the need to serve people or to take their situations of struggle into account. For all these reasons, such definitions are inadequate.

A broader definition of mission is the one developed by Bosch (1991:19), namely the participation of Christians in the liberating mission of Jesus Christ. It is the good news of God's love, incarnated in the witness of a community, for the sake of the world.

Two important points in this definition merit attention as far as this article is concerned, because they relate to both human development and Christian mission. These are participation and liberation. Participation means that mission is carried out not by a small minority (the ordained), but by all the people and this makes it developmental in its approach. Bosch (1991:467) holds that mission is ministry by all the people of God - both rich and the poor. He builds this understanding on the foundation laid by other theologians such as Jurgen Moltmann who says that 'Christian theology will no longer be simply a theology for priests and pastors, but also a theology for the laity in their calling in the world' (see Bosch 1991:467).

From development there was a move towards liberation. It was realised that poverty would not be uprooted by imposing technological skills on the poor, but by removing the root causes of injustice against the poor people. These two approaches to development converge with a new liberationoriented perception of mission in which it is understood as the total transformation of the whole of life and the realisation of God's shalom in both the present and the future.

I believe strongly that in the process of doing mission in the community of the poor people, mission should lead to liberation and social transformation. This means that it has to remove social, economic and political injustices that exist in those communities. It has to transform an oppressive situation to a non-oppressive one. If it does not do that, it is simply offering the 'pie in the sky' of salvation some day in heaven. This does not mean that anything that is done is mission: that would be simply activism. To make them mission, these works of liberation and social transformation need to be done in the name of Jesus Christ. Christians are to respond to the invitation of Christ himself who sanctioned us to go out and preach the gospel in ways that transform people's lives, because we cannot claim to be Christians and yet ignore the way things are organised around us. Our engagement as Christians is meant to infuse the values that uphold the dignity of all God's creation, especially all individual human beings. We are to help the development of social solidarity, the common good and special support for those impoverished and marginalised by our social, political and economic systems. It is in this sense that we are called upon to be the salt and light of the earth. According to Pope John XXIII (see Kaulema 2010):

Christianity is the meeting-point of heaven and earth. It lays claim to the whole man body and soul, intellect and will, inducing him to raise his mind above the changing conditions of this earthly existence and reach upwards for the eternal life of heaven, where one day he will find his unfailing happiness. Hence though the Church's first care must be for souls, how she (the Church) can sanctify them and make them share in the gifts of heaven, she concerns herself too with the exigencies of man's daily life, with his livelihood and education, and his general, temporal welfare and prosperity. (p. 77)

It is in this frame of mind, provided by the church, that Christians engage as the key players in all social, economic and political aspects that affect the 'caring of the souls'.

Church-based development, also known as faith based development, can be regarded as mission, because it is based on Christ's great commission to the church. It is done for the glory of God and in anticipation of his kingdom. It is not done for purely humanitarian reasons, but for reasons that transcend humanitarianism. Because we have better understanding now that the mission of the church, amidst all its ambiguities and the burden of history, is continually recast by communities that seek to shape their lives in light of the promise of the gospel. The church should always bear it in mind that mission begins with powerlessness and not power (Wickeri 2003:242)

\section{Back to basics}

According to Anne Hope (see Van Schalkwyk 1996:44), transformation can be understood as a process of change in people's attitudes and situations, leading to a change in their reality.

With my little experience in the ministry, transformation is viewed as an integral part of mission, because wherever mission is done, situations should be transformed, people's lives should change and their social conditions should improve. To buttress that statement, David Bosch (1991:1) 
says mission is an enterprise that transforms reality. I believe that mission makes a difference - it brings about lasting change wherever it is practiced. In this article mission focuses on transformation, and transformation should be the outcome of mission. Seen in this perspective, mission is that dimension of our faith that refuses to accept reality as it is, but seeks to transform it. It is with this understanding that the word mission is used in this article.

Development is the process by which members of a society increase their personal and institutional capacities to mobilise and manage resources to produce sustainable and justly distributed improvements in their quality of life consistent with their own aspirations (Mpumlwana 1997:18). The reason for development through mission, that is after the kingdom of God had been established in people's hearts, must clearly be to bring about the economic improvement as well as the social and political transformation of a community. Therefore, development is about the people - not projects or programmes. It has to be about improving the quality of life of ordinary people in their local communities.

I understand that development is not only an ambiguous concept, but also one that has become discredited and unpopular among communities on the receiving end of the so-called development work. This has happened, because the history of the concept is closely associated with Western ideas of modernisation, technological advancement, and liberal and free-market economic ideologies. Later it proved that this understanding of development is not good enough. It propagated colonisation and the disempowerment of the Third World countries by those of the First World. It failed to improve the economic, social and political lives of the poor in Third World countries. To some people the development aid became a tool for extending the dominance of Western culture. To solve this problem we need progressive understanding of development as a comprehensive social process that includes the interdependence of economic, social, political and cultural factors - both nationally and internationally (Van Schakwyk 1996:48). This understanding of development implies a challenge to the status quo and breaking down of oppressive structures, thus changing the perspective of development to that of liberation.

According to Van Schalkwyk (1996:48), the breaking down of negative structures is not enough for development. Once oppressive structures have been broken down by the liberating process of development, there is a need to build up a new society, and this process is called 'social transformation'. Anne Hope's view (see Van Schalkwyk 1996) is that:

social transformation implies building up a new society with an entirely different set of values as well as alternative economic, political, legal and educational structures which will create a just and equitable order. (p. 48)

When it comes to the relationship between the church and development, Koegelenberg (1992:3) says that the church should not take the issue of development with levity, because development is ultimately about a new vision for the society. It is about transformation of society from oppression to liberation, from poverty to well-being. Since God does not toy with people's pain, poverty and suffering, also the church should see people or human development as a serious matter.

\section{Conclusion}

There are observers who would perhaps argue that many development schemes in Africa have failed so spectacularly that Christian mission would do better to stay out of the debate, as mission and missiology have very little to contribute in any case. I differ from such an approach, and to the best of my knowledge, Africans mostly are proud and resourceful people who do not wish to survive in misery on hand-outs. They will most likely also have clear and workable ideas how their situation can be improved. In this sense it is important to point out that large-scale, national projects, which tend to characterise Western development projects, seldom 'work' in Africa. The reason for this is because the basic building block of society in Africa generally remains to be the smaller village, extended family or faith community. So 'bigger' is seldom 'better' in Africa - plans conceived at the centre (polis) are more likely to fail in simple human terms than plans conceived at the periphery (oikos). Despite the glaring poverty and apparent scarcity in so many African countries, 'life in abundance' is present and happens in networks of solidarity among the poor (cf. Saayman 2003:72). These networks are structured by the oikos, not the polis. This is where Christians in the oikoumene can join African Christians to develop an oikonomia that prioritises humanity - and this is an important future priority of mission and missiology.

\section{Acknowledgements}

I wish to express my gratitude to the Lord Almighty for his grace upon my life, and my late Professor/Promoter at the University of South Africa, Professor Willem A. Saayman, for being there for me always during his life time.

\section{Competing interests}

The authors declare that they have no financial or personal relationships which may have inappropriately influenced them in writing this article.

\section{References}

Alawode, A.O. \& Saayman, W.A., 2013, The future of Missiology, Lecture notes distributed in the Missiology Unit, University of South Africa.

August, K.T., 2006, The Nature of Interculturality in Development: A Theological Perspective of Relationality, Lecture notes distributed in the Department of Practical Theology, University of Stellenbosch, Stellenbosch.

Bosch, D.J., 1979, Heil vir die wêreld: Die Christelike sending inteologiese perspektief, NG Kerk Uitgewers, Pretoria.

Bosch, D.J., 1991, Transforming Mission: Paradigm shifts in Theology of Mission, Orbis Books, Maryknoll.

Bryant, L.M., 1999, Walking with the poor: Principles and practices of transformational development, Orbis Books, Maryknoll.

Burkey, S., 1993, People first: A guide to self-reliant participatory rural development, Zed Books, London.

De Beer, S., 1997, 'Towards a theology of inner city transformation: A contextual look at the church, housing and community in the inner city', PhD thesis, University of Pretoria, Pretoria. 
Faith in real life, 2013, Principles of Catholic social teaching, viewed 12 April 2016 from http://www.uscatholic.org/culture/social-justice

Kaulema, D. (ed.), 2010, Political participation in Zimbabwe, African Forum for Socia Teachings (AFCAST), Harare, Zimbabwe.

Koegelenberg, R.A., 1992, Church and development: An interdisciplinary approach: Perspectives from Southern Africa and Europe, EFSA, Johannesburg.

Kritzinger, J.J. \& Meiring, P.G.J., 1989, Mission as liberation, University of South Africa, Pretoria.

Medicalteams, 2013, 'Medical teams international', viewed 12 April 2016, from http://www.medicalteams.org

Mpumlwana, T., 1997, Women and development, South African Council of Churches, Johannesburg.

Opportunity International, 2000, Transformation indicators paper, distributed during Missiology Departmental Seminar, University of South Africa in 2011.
Saayman, W.A., 1980, 'Unity and mission: A study of the concept of unity in ecumenical discussion since 1961 and its influence of the world mission of the church', PhD thesis, University of Stellenbosch, Stellenbosch.

Saayman,W.A. (ed.), 1992, Enigste studiegids vir MSA 100-3: Inleiding tot die Sendingwetenskap, Universiteit van Suid-Afrika, Pretoria.

Saayman, W.A., 2003, “Ex Africa semper aliquid novi": Some random reflections on Challenges to Christian mission arising in Africa in the twenty-first century", Mission Studies 20(1), 39, 57-83. http://dx.doi.org/10.1163/157338303X00052

Transform world, 2009, 'Be transformed to transform, mission as transformation', viewed 12 April 2016, from http://transform-world.net

Van Schalkwyk, A., 1996, 'The Church, community development and liberation', Missionalia 24(9), 40-62.

Wickeri, P., 2003, Scripture, Community, and Mission, Clear-Cut, Hong Kong.

World Vision (WVI), 2003, Transformational development core documents, Monrovia, California, USA. 